\title{
The Students' Probabilistic Thinking Profile Based Cooperative Learning Numbered Heads Together (NHT) Type
}

\author{
Abdul Taram ${ }^{1}$, Fitri Ana Sari ${ }^{2}$, YL Sukestiyarno ${ }^{3}$, Rochmad $^{4}$, Iwan Junaedi ${ }^{5}$ \\ \{abdul.taram@pmat.uad.ac.id ${ }^{1}$, fitrianasari015@gmail.com², sukestiyarno@mail.unnes.ac.id ${ }^{3}$, \\ rachmad_manden@mail.unnes.ac.id ${ }^{4}$, iwanjunmat@mail.unnes.ac.id ${ }^{5}$ \}
}

Mathematics Education Study Program, Universitas Ahmad Dahlan, Yogyakarta, Indonesia ${ }^{1,2}$ Mathematics Education Study Program, Universitas Negeri Semarang, Semarang, Indonesia ${ }^{3,4,5}$

\begin{abstract}
This study aims to determine the students' probabilistic thinking profile level of grade IX-A SMP Muhammadiyah 3 Mlati in the learning process of Numbered Heads Together (NHT). This type of research was descriptive qualitative research with subjects in this study were drawn from grade IX-A SMP Muhammadiyah 3 Mlati which amounted to 22 students and elected 8 of the research subject.The technique of data collection in this study consisted of probabilistic problem-solving questions test and interview guidelines.The results showed that after being held of Numbered Heads Together (NHT) cooperative learning, it was obtained the conclusion (1) students' probabilistic thinking level 1 (Subjective) in solving the problem of probability were less likely to understand the questions, the strategy used tended to be out of the concept, the subject in the register space of the sample answered was less complete and had been difficulty in predicting an event,(2) students' probabilistic thinking level 2 (Transitional) in solving problems of probability tended to be a little added information, the subject was able to register complete of a set of one level experimental results, and in predicting and recording an event based on the opinions in quantitative terms but returned at subjective opinion, (3) students' probabilistic thinking level 3 (Informal Quantitative) in solving the problem of probability were able to provide information when retold the matter and tended to understand the subject, the used concepts tended to be correct, however there were strategies which were less precise, (4) students' probabilistic thinking level 4 (Numeric) in solving the problem of probability of being able to explain questions and answers, as well as performed calculations using the formula and the right steps, the subject was able to register complete of a set experimental results of two or three levels, and to mention the probability definitely.
\end{abstract}

Keywords: Thinking Profile, Probabilistic Thinking, and NHT

\section{Introduction}

Every mathematics learning activity of students will be treated to several mathematical problems. There are fundamental differences between students working on practice questions by solving problems in learning mathematics. In working on practice questions, students are only required to immediately get the answer. Pratiwi (2016: 15) states that a problem is a 
situation where an individual wants to do something but doesn't know the way of the action needed to get what he wants. Each student will respond to the problems they experience to produce the ability to connect something else to solve a problem and get new ideas. In this case, a thought process arises to be able to understand something that is being experienced (Mahyudi, 2017: 55).

Problem-solving in mathematics involves methods and methods of non-standard solutions that are not known in advance. Yuwono (2010: 35) states that solving problems in mathematics requires methods and methods of resolution that are not standardized and the truth is unknown in advance. According to Suherman, et al. (2003: 91) the solution to problem-solving contains four steps in the completion phase, namely: (1) Understanding the problem, (2) Planning a settlement, (3) Resolving the issue according to plan, and (4) Checking again. According to Sujadi (2008: 187) the mathematical problems are probabilistic because in reasoning, predicting and predicting students don't yet know the certainty. A probability situation is a problem that contains an element of uncertainty (a case involving change). The question that includes a part of change is a problem that refers to an activity or random experiment that can get different possible results, but the exact effects are not predetermined correctly. The term probabilistic thinking will be used to describe students' thinking in responding to various probabilistic problems.

It is challenging to find out about probabilistic students' thinking. Suppose students are given a problem related to the chance of an event, perhaps from the problem will get some answers to the same students. Sujadi (2008: 188) states that students' thinking in answering a probabilistic question has different levels of thinking. Students' knowledge of these opportunities is informal, namely knowledge that is built in non-academic settings, so it is possible to be different from the concept of opportunity formally, namely the concept of opportunities built in academic settings.

Taram (2016: 2) states that probabilistic thinking skills are one of the many variants of thought processes, and are classified in the high-level thinking process. The level or level of probabilistic thinking expressed by Jones et al (in Sujadi, 2008: 188) that there are four levels or levels of probabilistic thinking. Level 1 (Subjective): Thought students are constantly tied to subjective reasons. Level 2 (Transitional): is a period of transition between thinking subjective and thinking quantitatively, which is characterized by the thinking of students who often change (naive quantitative). Level 3 (Informal Quantitative): thinking at this level is shown through the use of generative strategies in registering the results of the 2-stage experiment and can harmonize and quantify their thoughts about the sample space and opportunities. Level 4 (numerical): students can make the right relationship about the sample space and its opportunities, and are able to use numerical measures correctly to describe the chance of an event.

Sugihartono, et al (2013: 74) states that learning is a process of changing behavior as a result of the interaction of individuals with their environment in meeting their needs. Regarding critical and creative thinking, students must continue to learn and learn, so a teacher must be clever to use what methods can be applied to students, especially in mathematics. Given that many mathematics lessons are not liked by students, the teacher must create active learning principles.

Based on observations on September 25, 2018, at SMP Muhammadiyah 3 Mlati the students tend to be passive in class, and lack interaction with teachers, activeness and independence of students in learning in most classes is still lacking. Some students even feel mathematics is a painful lesson. Teachers need to have the skills to interact with students and 
can choose the right learning model to deliver material so that students can be active in learning activities in school. According to Majid (2016: 176) learning by using cooperative methods allows students to work together to maximize their learning and learn other members in the group.

Cooperative learning refers to learning methods, where students work together in small groups to help each other in education. Group members are responsible for completing group tasks and for learning the material itself. Each group formed has different abilities. The principle of the cooperative learning model doesn't change, but there are several variations of the model (Suprihatiningrum, 2013: 191). Numbered Heads Together (NHT) is one of the cooperative learning models. Numbered Heads Together (NHT) is an approach developed by Spencer Kagen (1993) to involve more students in reviewing the material covered in a lesson and checking their understanding of the content of the experience (Suprihatiningrum, 2013: 209). The selection of the Numbered Heads Together (NHT) type of cooperative learning method is expected that learning can be more meaningful and give a strong impression on students so that students can increase the activity of learning in mathematics. Also, Numbered Heads Together (NHT) is expected to be able to help and encourage students who think that their probabilistic level is still low increases to a higher level.

This study aims to determine the students' probabilistic thinking profile level of grade IXA SMP Muhammadiyah 3 Mlati in the learning process of Numbered Heads Together (NHT).

\section{Research Method}

The method used in this research was descriptive qualitative research.The subjects in this study were drawn from grade IX-A SMP Muhammadiyah 3 Mlati which amounted to 22 students and elected 8 of the research subject. Items have never obtained opportunity material, and the researcher chooses each of the two things representing each level of probabilistic thinking. Data collection techniques used written tests and documentation. The instrument of data collection uses probabilistic thinking questions and interview guidelines. The results of probabilistic problem-solving tests and interviews were then presented and analyzed based on indicators of probabilistic thinking.

\section{Discussion}

Discussion of the results of research on the ability of students to solve probability problems in terms of probabilistic thinking indicators. Before the researcher took the data, the researcher conducted Numbered Heads Together (NHT) type cooperative learning on opportunity material. To facilitate understanding and discussion, the results of the study are presented by beginning with the data collection process, namely probabilistic thinking tests and interviews. Retrieving data from probabilistic thinking test results were obtained through problem-solving tests with 1 item description and given to 22 students grade IX-A SMP Muhammadiyah 3 Mlati. The probabilistic problem-solving analysis is used to classify/categorize the level of probabilistic thinking of each learner based on the probabilistic thinking indicators expressed by Jones (in Imam Sujadi, 2008). After the data is processed, it is obtained information that the highest level of probabilistic thinking in grade IX A SMP Muhammadiyah 3 Mlati is at level 1 (subjective), while the level of probabilistic thinking is at least level 3 (Informal Quantitative). 
After analyzing the test results of probabilistic thinking of students, the researchers then conducted interviews to find out more information about the profile of probabilistic thinking on the material opportunities. The interview data presented was obtained from research conducted on eight selected subjects with different levels, namely level 1 (subjective) selected by two subjects, level 2 (transitional) selected two subjects, level 3 (informal quantitative) selected two subjects, and level 4 (numeric) selected two subjects. The subject is based on consideration of the mathematics teacher SMP Muhammadiyah 3 Mlati who has the ability to convey ideas both verbally and in writing. The following eight subjects were selected for the researchers to conduct interviews:

Table 1. List of subject interviews based on probabilistic thinking levels

\begin{tabular}{ccc}
\hline Name of Subjct & Level & Code of subject \\
\hline IY & Level 1 & BP1 \\
RJN & Level 1 & BP2 \\
GES & Level 2 & BP3 \\
AG & Level 2 & BP4 \\
TWS & Level 3 & BP5 \\
DR & Level 3 & BP6 \\
AIA & Level 4 & BP7 \\
AL & Level 4 & BP8 \\
\hline
\end{tabular}

After the subject was chosen according to the level of probabilistic thinking raised by Jones (in Imam Sujadi, 2008), then the subject was given a problem-solving test based on probabilistic thinking indicators which amounted to 1 problem description. Questions were worked out within 20 minutes after conducting Numbered Heads Together (NHT) type learning. Then the subjects were interviewed one by one to get a more in-depth picture of the profile of probabilistic thinking of students in solving probability problems. To get the maximum interview results, all activities of the research subjects during the interview were recorded using cellphone recorders and cameras. The results of the interviews are then transcribed and encoded with capital letters and numbers that state the initials of the research subject.

From the results of interviews with the eight research subjects representing each level the following information was obtained:

Level 1 subject (Subjective).

Based on the results of the research on probabilistic thinking questions and the results of interviews on level 1 subjects in solving probability problems showed that the subject registered an incomplete set of one-level experimental results. It is evident that the subject is still confused and has difficulty registering a set. Subjects have not been able to analyze the problem and are still based on subjective opinions in predicting and recognizing an event. In answering questions, the subject doesn't use certain steps and only comes from answering. Evidently when interviewed, the subject is confusion whenanswering the issue. Subjects are only able to meet indicators of probabilistic subjective (level 1) level probabilistic thinking. Subjects in solving probability problems do calculations, but not based on mathematical models. It was proven that in the answer sheet the subject did not write down the completion steps or the formula used. During NHT cooperative learning level 1 subjects tend to be indifferent, less active in groups, and not paying attention during learning. So that it affects the results of probabilistic thinking tests that have been given. The following is an example of the answer sheet for probabilistic thinking level 1: 


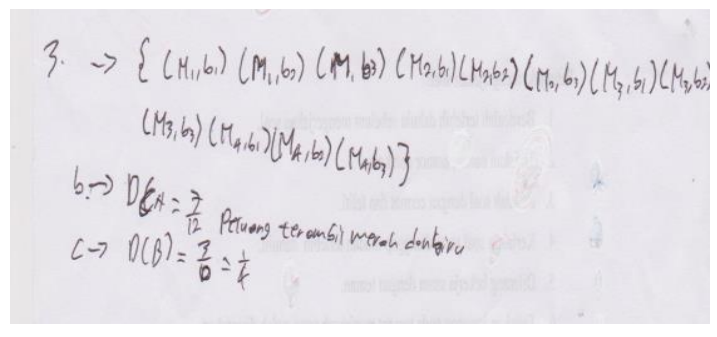

Fig. 1. Example of level 1 answer sheet

\section{Level 2 subject (transitional)}

Based on the results of the research on probabilistic thinking questions and the results of interviews on level 2 subjects in solving probability problems showed that the subject listed a complete set of results from a one-level experiment, sometimes registering the results of a twolevel experiment using a limited strategy. It is evident that the subject is still confused and has difficulty registering a complete and valid set. Subjects in predicting and recognizing an event based on opinions quantitatively but return to subjective opinions. In answering questions, the subject tries to use certain steps but is still based on subjective opinions. Evidently when interviewed the subject definitely answered the question, but sometimes in certain parts of the subject felt a sense of confusion to answer.

Subjects are able to fulfill indicators of probabilistic transitional level (level 2) probabilistic thinking. Subjects in solving probability problems do calculations, trying to use formulas and steps based on mathematical models. It was proven that in the answer sheet the subject wrote down the completion steps or the formula used. During NHT cooperative learning level 2 subjects tend to be indifferent, a little active in groups, and pay attention to learning. The following is an example of the answer sheet about probabilistic thinking level 2:

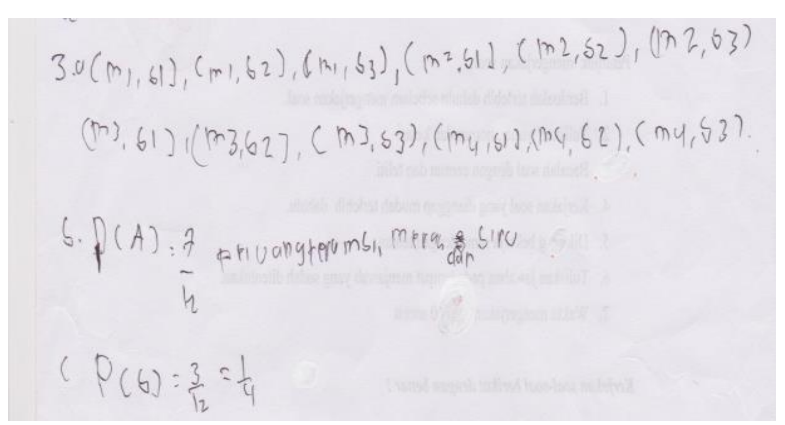

Fig. 2.Example of level 2 answer sheet

Level 3 subject (informal quantitative).

Based on the results of the research on probabilistic thinking questions and the results of interviews on level 3 subjects in solving probability problems showed that the subjects registered consistently the results of a two-level experiment. Subjects in predicting and recognizing an event based on opinions quantitatively. In answering questions, the subject tries to use generative steps and strategies, and has the ability to harmonize the sample space and 
opportunities. When interviewed the subject definitely answers the question and gives reasons with quantitative but valid reasoning.

Subjects are able to meet the probabilistic indicator of the level of informal quantitative (level 3) thinking probabilistic. Subjects in solving probability problems do calculations, and use formulas and steps based on mathematical models. It's evident that in the answer sheet the subject wrote a few steps for completing and using the formula. During NHT cooperative learning level 3 subjects are active in groups, often asking the teacher if they feel they don't understand and always pay attention when learning. The following is an example of the answer sheet for probabilistic thinking level 3:

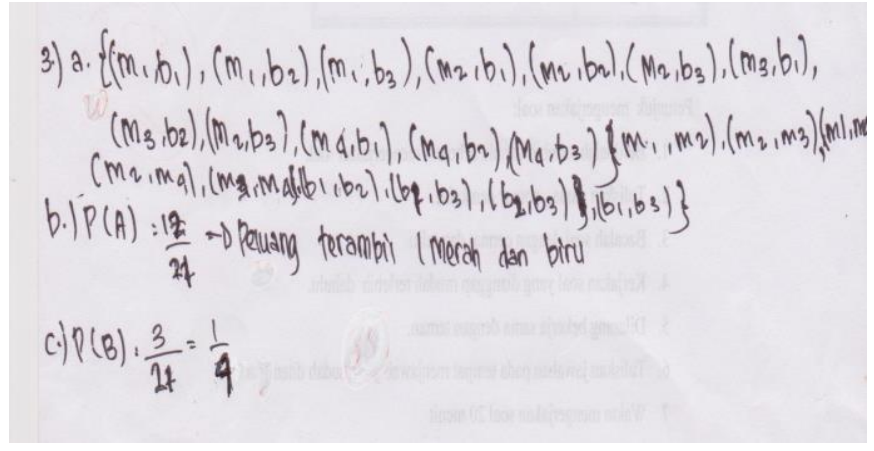

Fig.3. Example of level 3 answer sheet

Level 4 subject (Numeric).

Based on the results of a probabilistic thinking test and the results of interviews on level 4 subjects in solving probability problems showed that the subject applied and used generative strategies that made it possible to register in a complete and consistent two or three level experimental results. It is evident that on the answer sheet the subject adds certain information before registering all possible events. The subject in predicting and recognizing an event mentions with certainty and is able to use numerical measurements correctly. In answering questions, the subject uses the right steps and formulas. When conducting an interview the subject definitely answers the question and is able to describe the opportunity of an event precisely.

Subjects are able to meet probabilistic thinking indicators of numerical (level 4) probabilistic thinking. Subjects in solving probability problems do calculations, and use formulas and steps based on mathematical models. It is evident that in the answer sheet the subject writes the completion steps and uses the right formula. During NHT cooperative learning level 4 subjects are very active in groups, often asking the teacher if they feel they don't understand and always pay attention when learning. The following is an example of the answer sheet for probabilistic thinking level 4: 


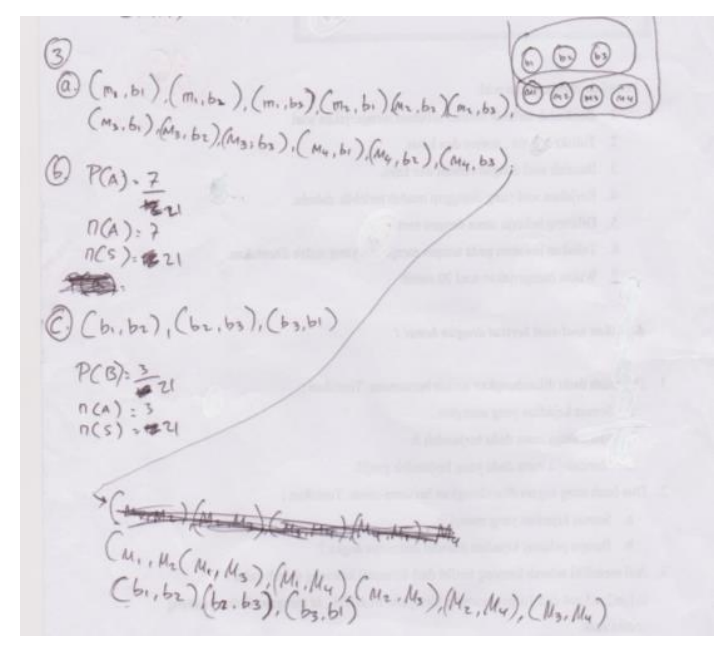

Fig. 4. Example of level 4 answer sheet

\section{Conclusion}

Based on the results of research and discussion in chapter IV regarding the profile of probabilistic thinking of students based on cooperative learning of Numbered Heads Together (NHT) type, it can be conclude that:

Profile of probabilistic thinking of level 1 (subjective) students in solving probability problems after NHT learning tends to lack understanding of questions. The strategies used tend to be out of concept. The subject in registering the sample room answers incomplete and still has difficulty predicting an event.

Profile of probabilistic thinking level 2 (transitional) students in solving probability problems after NHT learning tends to add a little information. Subjects are able to register a complete set of results at a one-level experiment, but sometimes register with a complete twolevel experiment using a limited strategy. In predicting and registering an event based on opinion quantitatively but returning to subjective opinions.

Profile of probabilistic thinking level 3 students (informal quantitative) in solving probability problems after NHT learning is able to provide information when retelling the problem and tend to understand the problem. The concepts used tend to be right, but there are strategies that are not right. Subjects were able to register consistently the results of two-level experiments and in predicting events based on opinions quantitatively.

Profile of probabilistic thinking on level 4 (numeric) students in solving probability problems after NHT learning is able to explain these questions and answers, and do calculations using appropriate formulas and steps. The subject is able to register a complete set of experimental results of two or three levels, and states with certainty the chance of an event. 


\section{References}

[1] Majid, A. 2016. Strategi Pembelajaran. Bandung: PT Remaja Rosdakarya.

[2] Mahyudi. 2017. Proses Berpikir Probabilistik Siswa dalam Mengkonstruksi Konsep Permutasi dan Kombinasi. Jurnal Edumatica Volume 07 Nomor 01 April 2017: Program Studi Pendidikan Matematika FKIP UNB.

[3] Pratiwi,R. 2016. Profil Intuisi Siswa Kelas IX SMP Negeri 3 Salatiga dalam

[4] Memecahkan Masalah Kesebangunan Ditinjau dari Kecerdasan Matematis-logis, Kecerdasan Linguistik, dan Kecerdasan Visual Spasial. Tesis. Tidak dipublikasikan. Surakarta: Program Pascasarjana UNS.

[5] Sugihartono, dkk. 2013. Psikologi Pendidikan. Yogyakarta: UNY press.

[6] Sugiyono. 2017. Metode Penelitian Pendidikan: Pendekatan Kuantitatif, kualitatif, dan R\&D. Bandung: Alfabeta.

[7] Suherman. 2003. Teori Pemecahan Masalah Polya Dalam Pembelajaran Matematika. Jurnal. Diunduh tanggal 23 Desember 2018.

[8] Sujadi, I. 2008. Rekonstruksi Tingkat-tingkat Berpikir Probabilistik Siswa Sekolah

[9] Menengah Pertama. Semnas Matematika dan Pendidikan Matematik: UNS. Diunduh tanggal 28 September 2018; http://eprints.uny.ac.id/id/eprint/6925; internet.

[10] Suprihatiningrum, J. 2016. Strategi Pembelajaran. Yogyakarta: Ar-Ruzz Media.

[11] Taram, A. 2016. Proses Berpikir Probabilistik Mahasiswa SI Pendidikan Biologi

[12] JPMIPA FKIP UAD Pada Pokok Bahasan Teori Probabilitas. Jurnal AdMathEdu Volume 6 No. 1 hal. 1-10 Juni 2016: Program Studi Pendidikan Matematika FKIP UAD.

[13] Yuwono, A. 2010. Profil Siswa SMA dalam Memecahkan Masalah Matematika Ditinjau dari Tipe Kepribadian. Tesis. Tidak Dipublikasikan. Surakarta: Program Pascasarjana UNS. 